\title{
Mütəxəssis Biliyinin Testləşdirilməsi Proqram Paketinin Layihələndirilməsi
}

\author{
Məhəmməd Ohmədov ${ }^{1}$, Şəfahət Rəhimov ${ }^{2}$, Zakir Sadiqov ${ }^{3}$ \\ ${ }^{1,2,3}$ Sumqayıt Dövlət Universiteti, Azərbaycan \\ sadiqovzakir@mail.ru
}

\begin{abstract}
Xülasə- Təqdim olunan tezisdə respondentin, yəni sorğu edilən şəxsin biliyinin və bacarı̆̆ının qiymətləndirilməsi üçün proqram paketinin işlənməsi məsələsinə baxılmış, testin aparılmasının struktur sxemi işlənmiş vo müvafiq proqram paketi yaradılmışdır.
\end{abstract}

Açar sözlor- testloşdirmo, kompüter, avtomatlaşdırma, struktur sxem, respondent, proqram, layiho

\section{GIRISS}

İnsanın əqli fəaliyyətinin modelləşdirilməsi,o cüm-lədən tələbənin, mütəxəssisin biliyinin qiymətləndirilməsi üçün proqram paketlərinin layihələndirilməsi son zamanlar proqram mühəndisliyinin mühüm sahələrindən birinə çevrilmişdir. Aydındır ki, predmet sahəsi üzrə mütəxəssisin biliyinin və qabiliyyətinin ekspert (predmet sahəsi üzrə aparıci mütəxəssis) tərəfindən yoxlanılması həm çox vaxt aparan, həm də subyektiv bir proses olduğu üçün, bu problemin həllində kompüterin tətbiqi məqsədəuyğun və aktualdır.

\section{STRUKTUR SXEMIN İSLONILMOSI}

Testləşdirmə, avtomatlaşdırılmış informasiya sisteminin (TAİS) struktur sxemi [1] və alqoritminə əsasən sistemin proqram təminatının[2] işlənməsi,bu sistemin fəaliyyəti və tətbiqi, tezisdə qarşıya qoyulan əsas məqsəddir.

Layihələndirilən TAİS-in funksiyalarından biri də predmet sahələri üzrə mütəxəssis biliklərinin qiymətləndirilməsi üçün test üsulu ilə elektron yoxlama və nəticələrin mərkəzləşdirilmiş emal edilməsidir. Biliyin qiymətləndirilməsi vasitələrindən biri kimi qəbul olunan test üsulu bu gün də öz aktuallığını saxlamaqdadır. Üsulun üstünlüklərindən biri kimi biliyin qiymətləndirilməsində dəqiqliyin yüksək olmasını göstərmək olar. Lakin digər tərəfdən test banklarının tərtibi, onların yeniləşməsi və sualların çətinlik dərəcələrinə görə seçilməsi yorucu olmaqla yanaşı, həm də vaxt tələb edir. Bu və digər çətinlikləri nəzərə alaraq təqdim olunan tezisdə test üsulu ilə qiymətləndirmənin avtomatlaşdırılması məsələsinə baxilır.

Predmet sahəsi üzrə mutəxəssisin biliyinin qiymətləndirilməsi üçün proqramlar paketinin layihələndirilməsinin ümumi strukturunu aşağıdakı kimi təklif etmək olar.

Təklif olunan TAİS alqoritmi əsasən beş moduldan (şəkil.1) ibarətdir[3]:

- server- proqram modulundan;

- biliyin qiymətləndirilməsi ücün VB-nin işlənməsi modulundan:

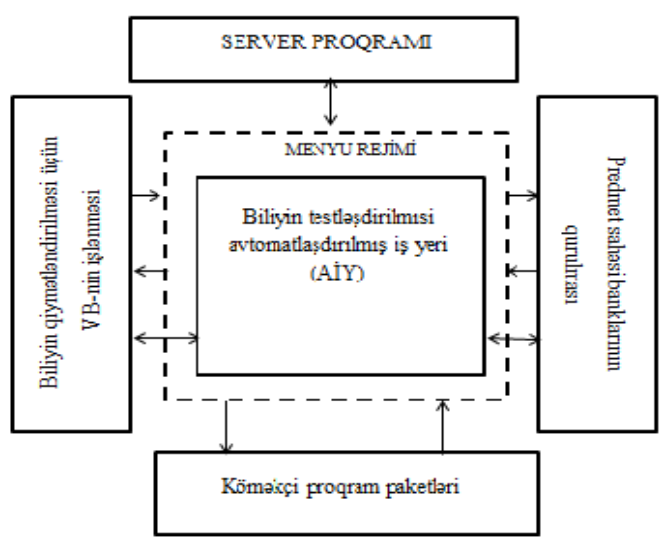

Şəkil 1. Test üsulu ilə qiymətləndirilmənin avtomatlaşdırılması sxemi

- predmet sahəsi banklarının yaradılması modulundan;

- biliyin testləşdirilməsi üçün avtomatlaşdırılmış iş yeri (AIY) modulundan;

- köməkçi proqram paketləri modulundan.

Köməkçi proqram paketi isə aşağıdakı modullardan ibarətdir:

1. test bankının yaradılması;

2. test bankının yoxlanılmasi;

3. test suallarının mürəkkəblik dərəcələrinə görə qruplaşdırılması;

4. testin aparılması:

4.1. mövzunun seçilməsi;

4.2. sualların ümumi sayının seçilməsi

4.2.1. açıq və qapalı tipli sualların sayının təyini;

4.3. vaxtın təyini.

5. testin nəticələrinin saxlanılması və çap olunması;

6. yeni respondentin məlumatlarının daxil edilməsi.

Server proqram modulu “müştəri kompüter”lərin sayını və onlar arasındakı əlaqənin mümkünlüyünü müəyyənləşdirir. Müştəri kompüter kimi qəbul olunan hər bir respondent şəbəkədən ayrılarsa, dərhal serverə informasiya ötürülür. Serverə ötürülən informasiyanın strukturu əsasında konkret olaraq respondentin soyadı, adı, atasının adı və ilkin bal 
göstəricisi müəyyənləşdirilir ki, bu da digər müştəri kompüterlərə aid olmayan informasiyanın ötürülməsinin qarşısını alır. Server proqram modulunun icazəsindən sonra biliyin testləşdirilməsi ücün AİY modulu aktivləşir.

Sistem tərəfindən təklif olunan istifadəci interfeysi sadə olub,minimal informasiya daxil edilməsini tələb edir.Bu rejimdə respondent öz kodunu daxil etdikdən sonra təsdiqləyir. Kod düzgün daxil edilməyibsə, "kodun yanlış " olması haqqında məlumat verilir. Qeyd etmək lazımdır ki, kod yaddan çıxarsa, respondentin adının, soyadının və digər məlumatların əsasında da kodun təyini icra oluna bilər.

Kodun düzgün daxil edilməsindən sonra sual bankından ixtiyari qaydada suallar seçilir. Respondent hər hansı sualı cavablandırarkən, cavabın yalan və ya doğru olması haqqında məlumat verilir. Respondentin seçdiyi variant və düzgün cavabın variantı isə xüsusi tərtib olunmuş cədvəldə əks etdirilir,həmçinin seçilən sualları nəzərdən keçirməklə cavablandırma ardıcıllığını da dəyişə bilər.

AIYY modulu hər bir sualın təhlilini də aparır. Belə ki, sualın çətinlik dərəcəsinin təyini sualı cavablandıranların faiz nisbətinə görə müəyyənləşdirilir.

Test bankının qurulması modulu "WORD"-də tərtib olunmuş fənn banklarının oxunmasının və onların verilənlər bazası şəklində saxlanmasını təmin edir.

Respondentlorin siyahısının hazırlanması, onların kodlaşdırılması mexanizminin icrası isə predmet sahələri banklarının qurulması modulu vasitəsi ilə yerinə yetirilir.

Köməkçi proqramlar isə bankdan seçilən sualların dəyişdirilməsi, imtahan vaxtının müəyyənləşdirilməsi, tələbənin axtarışı, cədvəllərin çapı və s. kimi əməliyyatları yerinə yetirir.

\section{NəTIC๐}

WORD-də verilən sual bankının məxfiliyi təmin edilir. Bank suallarının modifikasiya olunması is y yalnız server tərəfindən xüsusi kodla aparılır. Proqram Delfi [1] və Builder$\mathrm{C}++$ [2] alqoritmik dillərinin birgə tətbiqi əsasında tərtib edilmiş və sınaqdan keçirilmişdi. Nəticə qənaətbəxş olmuşdur.

\section{ӘDӘВIYYYAT}

[1] М.Е. Фленов, Библия Delphi.- СПб; БХВ.- Петербург 2009

[2] Е.В. Кондратюк,Builder-C++ - Трюки и эффекты СПб; БХВ.Питер, 2006.

[3] Ş.R.Rəhimov, Z.Ә.Sadıqov,S.A.Xəlilov,İ.S.Zeynalabdıyeva, Elektron tədris informasiyasistemlərinin proqram təminatının işlənməsi. Elmi xəbərlər. Təbiət və texniki elmlər bölməsi. Cild 11, №2, Sumqayıt 2011, səh. 99-102. 